\title{
Small store presence in Japan
}

\author{
Martin A. Carree \\ Erasmus University, PO Box 1738, 3000 DR Rotterdam, Netherlands \\ Research Institute for Small and Medium-Sized Business, PO Box 7001, 2701 A A Zoetermeer, Netherlands
}

\section{Jeroen C.A. Potjes}

Erasmus University, PO Box 1738, 3000 DR Rotterdam, Netherlands

Internationale Nederlanden Group, PO Box 29701, 2502 LS The Hague, Netherlands

\author{
A. Roy Thurik ${ }^{\dagger}$ \\ Erasmus University, PO Box 1738, 3000 DR Rotterdam, Netherlands \\ Research Institute for Small and Medium-Sized Business, PO Box 7001, 2701 AA Zoetermeer, Netherlands
}

Received 23 July 1992

Final revision received 23 December 1992

Accepted 3 March 1993

\begin{abstract}
The determinants of the development of small store presence in Japan are investigated using a fixed effects multinomial logit market share model. Large stores tend to have higher market shares in shop-types with increasing shares in consumer expenditures, increasing inventory turnover, and increasing diversification, but do not seem to be able to profit from scale economies in labour use.
\end{abstract}

\section{Introduction}

The abundance of small stores in Japanese retailing is often considered to be an impediment to imports of American and European products into Japan [US International Trade Commission (1990)]. Small retailers would not only be more reluctant to sell foreign products than large stores [Batzer and Laumer (1989) and Montgomery (1991)], but also use their political power to prevent the establishment of large stores. Considerable political pressure from small retailers of the leading Liberal Democratic Party has led to the enactment of the Large Scale Retail Store Law [Kirby (1983), Kurebayashi (1991)]. This law favours small stores in three ways. First, the small stores are allowed to have more flexible opening hours than the large stores. Second, the law only allows for the establishment of a large-scale retail store with the prior consent of the small retailers in the area. Third, the complex procedures to obtain the consent of the retailers delay the establishment of the large-scale stores considerably, sometimes by 10 years [US International

\footnotetext{
${ }^{*}$ The authors wish to thank David B. Audretsch, René A. Belderbos and H. Edwin Romeijn for useful comments. Carree gratefully acknowledges the financial support from the Netherlands Organisation for Scientific Research (NWO).

Correspondence to: A.R. Thurik, Erasmus University, PO Box 1738, 3000 DR Rotterdam, Netherlands.
} 
Trade Commission (1990)]. The US Congress has been exercising strong political pressure on the Japanese government to decrease the impediments to large-scale retail enterprises and in particular to repeal this Large Scale Retail Store Law. This pressure resulted in an amendment of the Law in 1990, which made the establishment procedures of large-scale stores less complicated and less time consuming.

Small store sales shares in Japan are high. In 1988 these shares were $11 \%, 28 \%$ and $49 \%$ for stores with 1-2, 1-4 and 1-9 employees (shopkeeper and working family members included), respectively. This high share of smallness is reflected by the high number of stores per 1000 inhabitants: 13.6 in Japan and 3.5 in the United States for 1985 [Census of Commerce (1985) and Ravesloot and Vogelesang (1989)]. The high small store presence can be attributed to a number of factors. First, Japanese prefer fresh goods and usually have only very limited home storage capacity and therefore greatly value nearby stores [Flath (1990)]. Second, many small stores offer an important local function as neighbourhood meeting points [Bestor (1989)]. Third, in many cases stores are established to generate income during retirement years or to supplement family income. By screening out certain groups, in particular women, and by retiring workers early, large firms create large pools of people having a high potential of starting their own firm [Caves and Uekusa (1976), Patrick and Rohlen (1987)]. Fourth, small businesses are protected by laws imposing obstacles to the establishment of large stores [Kirby (1983), Kurebayashi (1991)]. Small retailers not only profit from the Large Scale Retail Store Law, but are also not obliged to administrate their transactions. They pay less taxes, and do not have to collect the $3 \%$ consumption tax. Fifth, small stores profit from low retailer reorder costs [Flath (1990)]. Japan has a highly developed wholesaling network with relatively small distances between producers, wholesalers and retailers. And sixth, the purpose of being in business is not always to generate income, but often to protect claims on land and to maintain advantageous property tax arrangements [Patrick and Rohlen (1987)]

The purpose of the present study is to explain the differences in the development of small store presence across shop-types. A fixed effects multinomial logit market share model is used to investigate the effects of shop-type characteristics (i.e. industry-specific variables) which may enhance opportunities for large retail store market share expansion, like growing shares of the shop-type in total consumer expenditures, growing inventory turnover, growing extent of diversification, and high productivity differentials between small and large stores. Similar determinants have been used in recent studies to explain the presence of small businesses in the manufacturing industries [White (1982), Acs and Audretsch (1989a, b), Schwalbach (1989)]. Our study, however, is the first to explain the presence of small firms in retailing, one of the major service industries.

\section{Determinants of small store presence}

The extent of small stores depends directly upon the degree to which large stores maintain or improve their market positions. Shop-types with low and declining total consumer expenditure shares are usually unattractive to large-scale stores and are increasingly dominated by small stores. Like single products, shop-types show a life-cycle in which various stages can be discerned. Shop-types in the early stages of their life-cycle are more appropriate environments for large store market share expansions leading to the ousting of smallness than shop-types in the late stages of their life-cycle. We incorporate the change in the share in total consumer expenditure, $D M S$, in our model as an indicator of these life-cycle effects. We make a distinction between growing, $D M S^{+}$, and declining, $D M S^{-}$, market shares to allow for different effects in early and late stages 
of the life-cycle. The variable $D M S^{+}=D M S$ if $D M S \geqq 0$ (and 0 elsewhere) and the variable $D M S^{-}=D M S$ if $D M S<0$ (and 0 elsewhere).

We also incorporate the change of inventory turnover, DIT. Inventory turnover is defined as the value of inventory divided by the value of sales. A growing inventory turnover points to changing consumer preferences towards more low-cost, low-service retailing, which would create competitive advantages for larger stores. Larger stores are also expected to gain market share as diversification becomes more profitable. Diversification is measured as the change in the ratio of total sales to sales in the main product-line of a shop-type, $D D V$.

Fconomies of scale, measured by the productivity differential between large and small stores, are expected to exert a positive effect on the growth of the market share of large firms. We incorporate a measure of the level of economies of scale, ECS, as calculated by the sales to employment ratio of large stores (more than 9 employees) divided by the sales to employment ratio of very small stores (1-2 employees). This variable is an average over the preceding 3-year period (a 2-year period for 1974 and 1976). This indicator of economies of scale is about 2 in most shop-types, illustrating the relative inefficiency of the very small stores.

Growing total consumer expenditure share, growing inventory turnover, growing diversification, and high economies of scale are all hypothesized to have a negative effect on the small store presence. We explicitly discriminate between effects on very small (1-2 employees), small (3-4 employees) and medium-sized (5-9 employees) stores in our market share model because these size classes have different properties. Ability and eagerness to grow will be lowest among the very small family-run firms, while medium-sized firms may not differ in growth potential and objectives from their larger counterparts [Patrick and Rohlen (1987)]. They often use the same competitive instruments as large firms do, implying that they will possibly bencfit more from legal obstacles to large establishment than small stores do. All four determinants are therefore supposed to have a negative effect for stores with 1-2, 3-4 and 5-9 employees, but decreasingly so with store size.

We investigate the effects of these determinants using a multinomial logit model. This method has never been applied to identify the determinants of the firm-size distribution, although it is commonly used in market share analysis [Cooper and Nakanishi (1988)]. The following formulation for the market share of firm-size class $j$ in shop-type $i$ and year $t$ is chosen:

$$
m_{i j t}=\frac{\exp \left(\alpha_{i j}+\beta_{j t}+X_{i t}^{T} \gamma_{j}+\epsilon_{i j t}\right) m_{i j, t-1}}{\sum_{k=1}^{K} \exp \left(\alpha_{i k}+\beta_{k t}+X_{i t}^{I} \gamma_{k}+\epsilon_{i k t}\right) m_{i k, t-1}} \text { for } j=1, \ldots, K
$$

We use a fixed effects specification to control for shop-type, $\alpha_{i j}$, and time-specific, $\beta_{i t}$, effects. The elements of $X_{i t}$ are logarithmic transformations of the explanatory variables $D M S_{i t}^{+}, D M S_{i t}^{-}$, $D I T_{i t}, D D V_{i t}$, and $E C S_{i t}$. Assuming $\alpha_{i K}=0, \beta_{K t}=0$ and $\gamma_{K}=0$, which implies that the $K$ th size class (containing the largest enterprises) is used as benchmark, we obtain the following equations to be estimated:

$$
\Delta \log \left(\frac{m_{i j t}}{m_{i K t}}\right)=\alpha_{i j}+\beta_{j t}+X_{i t}^{T} \gamma_{j}+\epsilon_{i j t}-\epsilon_{i K t} \quad \text { for } j=1, \ldots, K-1
$$

The market share, $m_{i j t}$, will be expressed in both the number of firms and the amount of sales. This allows for an investigation of whether small stores remain in business despite serious market sharc losses. Many small stores are known to be in business to protect claims on land or to maintain advantageous property tax arrangements [Patrick and Rohlen (1987)]. Growing competitive advantages for large stores may therefore lead to a decreasing small store presence when 
measured by the amount of sales but nevertheless have little or no effect on the small store presence when measured by the number of stores.

\section{Results}

Our data include 56 shop-types over the 1974-1988 period (Source: Census of Commerce). Six separate years $(1974,1976,1979,1982,1985$ and 1988) are available, yielding a total of 336 observations. Four size classes are used: 1-2 persons, 3-4 persons, 5-9 persons and more than 9 persons employed (shopkeeper and working family members included). The growth of the small store market share differs strongly across shop-types. It ranges between $-77 \%$ for kitchenware stores and $145 \%$ for fixture stores and has a mean value of $12 \%$ for the 1974-1988 period. A table with a full survey of small store presence and its growth for all shop-types is available from

Table 1

Estimates of the fixed effects multinomial logit market share model

\begin{tabular}{|c|c|c|c|c|c|c|c|c|}
\hline \multirow[t]{2}{*}{ Variable } & \multicolumn{4}{|c|}{ Number of firms } & \multicolumn{4}{|c|}{ Amount of sales } \\
\hline & $1-2$ & $3-4$ & $5-9$ & $F^{\mathrm{a}}$ & $1-2$ & $3-4$ & $5-9$ & $F^{\mathrm{a}}$ \\
\hline$D_{1974}$ & $\begin{array}{l}0.137 \\
(1.4)\end{array}$ & $\begin{array}{l}0.168 \\
(1.8)\end{array}$ & $\begin{array}{l}0.118 \\
(1.3)\end{array}$ & 2.30 & $\begin{array}{l}0.144 \\
(1.1)\end{array}$ & $\begin{array}{l}0.190 \\
(1.4)\end{array}$ & $\begin{array}{l}0.061 \\
(0.4)\end{array}$ & 1.07 \\
\hline$D_{197 \hbar}$ & $\begin{array}{l}0.044 \\
(0.5)\end{array}$ & $\begin{array}{l}0.093 \\
(1.1)\end{array}$ & $\begin{array}{l}0.066 \\
(0.8)\end{array}$ & 0.75 & $\begin{array}{l}0.165 \\
(1.4)\end{array}$ & $\begin{array}{l}0.195 \\
(1.6)\end{array}$ & $\begin{array}{l}0.101 \\
(0.8)\end{array}$ & 1.72 \\
\hline$D_{1979}$ & $\begin{array}{l}0.015 \\
(0.2)\end{array}$ & $\begin{array}{l}0.062 \\
(0.8)\end{array}$ & $\begin{array}{l}0.059 \\
(0.7)\end{array}$ & 0.38 & $\begin{array}{l}0.109 \\
(0.9)\end{array}$ & $\begin{array}{l}0.124 \\
(1.0)\end{array}$ & $\begin{array}{l}0.054 \\
(0.4)\end{array}$ & 0.69 \\
\hline$D_{19 \times 2}$ & $\begin{array}{c}-0.012 \\
(0.2)\end{array}$ & $\begin{array}{l}0.022 \\
(0.3)\end{array}$ & $\begin{array}{l}0.024 \\
(0.3)\end{array}$ & 0.06 & $\begin{array}{l}0.117 \\
(1.0)\end{array}$ & $\begin{array}{l}0.131 \\
(1.1)\end{array}$ & $\begin{array}{l}0.064 \\
(0.5)\end{array}$ & 0.82 \\
\hline$D_{1985}$ & $\begin{array}{l}-0.128 \\
(1.6)\end{array}$ & $\begin{array}{l}-0.013 \\
(0.2)\end{array}$ & $\begin{array}{l}0.008 \\
(0.1)\end{array}$ & 0.85 & $\begin{array}{l}0.023 \\
(0.2)\end{array}$ & $\begin{array}{l}0.097 \\
(0.8)\end{array}$ & $\begin{array}{l}0.053 \\
(0.4)\end{array}$ & 0.30 \\
\hline$D_{1988}$ & $\begin{array}{l}-0.225^{\circ} \\
(2.8)\end{array}$ & $\begin{array}{c}-0.091 \\
(1.1)\end{array}$ & $\begin{array}{l}-0.027 \\
(0.3)\end{array}$ & $3.03^{\mathrm{e}}$ & $\begin{array}{c}-0.080 \\
(0.7)\end{array}$ & $\begin{array}{c}-0.007 \\
(0.1)\end{array}$ & $\begin{array}{l}-0.016 \\
(0.1)\end{array}$ & 0.16 \\
\hline $\begin{array}{l}\text { Growing expenditure } \\
\text { share }\left[D M S^{+}\right]\end{array}$ & $\begin{array}{l}-0.595^{e} \\
(3.0)\end{array}$ & $\begin{array}{l}-0.392^{\circ} \\
(2.0)\end{array}$ & $\begin{array}{c}-0.135 \\
(0.7)\end{array}$ & $4.50^{\circ}$ & $\begin{array}{l}-0.646^{\circ} \\
(2.3)\end{array}$ & $\begin{array}{c}-0.527 \\
(1.8)\end{array}$ & $\begin{array}{c}-0.120 \\
(0.4)\end{array}$ & $2.89^{\mathrm{e}}$ \\
\hline $\begin{array}{l}\text { Declining expenditure } \\
\text { share }\left[D M S^{-}\right]\end{array}$ & $\begin{array}{c}-0.569^{\circ} \\
(4.4)\end{array}$ & $\begin{array}{l}-0.451^{c} \\
(3.6)\end{array}$ & $\begin{array}{c}-0.234 \\
(1.8)\end{array}$ & $11.87^{\circ}$ & $\begin{array}{l}-1.005 \\
(5.4)\end{array}$ & $\begin{array}{l}-0.921^{c} \\
(4.9)\end{array}$ & $\begin{array}{l}-0.535 \\
(2.6)\end{array}$ & $20.31^{\circ}$ \\
\hline $\begin{array}{l}\text { Inventory turnover } \\
\quad[D I T]\end{array}$ & $\begin{array}{l}-0.051 \\
(0.5)\end{array}$ & $\begin{array}{l}0.005 \\
(0.0)\end{array}$ & $\begin{array}{l}0.022 \\
(0.2)\end{array}$ & 0.08 & $\begin{array}{l}-0.479^{\mathrm{c}} \\
(3.0)\end{array}$ & $\begin{array}{c}-0.294 \\
(1.8)\end{array}$ & $\begin{array}{c}-0.260 \\
(1.5)\end{array}$ & $4.71^{\mathrm{e}}$ \\
\hline $\begin{array}{l}\text { Diversification } \\
{[D D V]}\end{array}$ & $\begin{array}{c}-0.141 \\
(1.7)\end{array}$ & $\begin{array}{l}-0.124 \\
(1.5)\end{array}$ & $\begin{array}{c}-0.135 \\
(1.7)\end{array}$ & $2.72^{e}$ & $\begin{array}{l}-0.289^{\mathrm{e}} \\
(2.5)\end{array}$ & $\begin{array}{l}-0.229 \\
(1.9)\end{array}$ & $\begin{array}{l}-0.236 \\
(1.8)\end{array}$ & $4.39^{c}$ \\
\hline $\begin{array}{l}\text { Scale economies } \\
\quad[E C S]\end{array}$ & $\begin{array}{l}0.015 \\
(0.5)\end{array}$ & $\begin{array}{l}0.002 \\
(0.3)\end{array}$ & $\begin{array}{l}0.032 \\
(0.2)\end{array}$ & 0.08 & $\begin{array}{l}-0.162 \\
(1.6)\end{array}$ & $\begin{array}{c}-0.135 \\
(1.3)\end{array}$ & $\begin{array}{c}-0.039 \\
(0.3)\end{array}$ & 1.46 \\
\hline Mean ${ }^{b}$ & -0.0313 & -0.0057 & -0.0028 & & -0.0280 & -0.0111 & -0.0107 & \\
\hline$D W^{c}$ & 1.80 & 1.89 & 1.78 & & 1.88 & 1.85 & 1.89 & \\
\hline$F^{d}$ & $10.76^{\circ}$ & $6.18^{\circ}$ & 1.99 & & $16.94^{\circ}$ & $11.64^{\circ}$ & $3.63^{\mathrm{e}}$ & \\
\hline$R^{2}$ & 0.674 & 0.549 & 0.297 & & 0.553 & 0.443 & 0.230 & \\
\hline
\end{tabular}

Note: Least squares estimates of multinomial logit model with time dummies and shop-type dummies (not presented) included. Numbers in parentheses are $t$-statistics.

a Tests of hypotheses of no dummy variable effect $\left[\beta_{j,}=0\right]$ or no shop-type characteristic effect $\left[\gamma_{i j}=0\right]$.

${ }^{b}$ Mean of dependent variable $\left[\Delta \log \left(m_{i j t} / m_{i 4 i}\right)\right]$.

' Durbin-Watson test-statistic.

d Tests of hypotheses of no non-dummy variables effect $\left[\gamma_{j}=0\right]$.

'Significant at $5 \%$ significance level. 
the authors. In Table 1 , the parameter estimates of time dummies $\left(\beta_{j t}\right)$ and shop-type characteristics $\left(\gamma_{1}\right)$ are presented. The table has three dimensions: variables, number of firms versus amount of sales, and size-classes. We will discuss the results in that order.

We find that growing as well as declining share in consumer expenditure, growing inventory turnover, and growing diversification are negatively related to the small store presence. $F$-tests of these four shop-type characteristics show that their contribution is significant in seven out of eight (four charactcristics for both number of firms and amount of sales) cases. Howcver, scale economies have no effect on small store market shares. This means that large-scale stores were not able to translate their more productive use of labour into larger market shares in the 1974-1988 period. The negative coefficient of the declining share in consumer expenditure indicates that the share of small stores increases in these low-growth shop-types. Examples of shop-types with strongly declining consumer expenditure shares and strongly increasing small store presence are fixture stores, dry goods and dress materials stores, and chinaware and glassware stores. In shop-types with an increasing share of consumer expenditure (high-growth shop-types), however, small business presence tends to decline. Modern shop-types, like kitchenware stores, grocery stores, and delicatessen stores, tend to have increasing shares in Japanese consumer expenditures. Market positions for American and European products will likely improve because shop-types with growing large store dominance are amongst the fastest growing in Japanese retailing.

The time-dummy coefficients are generally declining over time. This decline may be the result of the increasing retirement of shopkeepers with no successor [Suzuki (1991)] and by a decreasing number of people starting their own small family enterprise [Potjes et al. (1992)]. The latter cause is suspected to result from an increase in demand for labour by the highly respected large manufacturing and service enterprises. In fact, from 1970 to 1982 , there were between 42,000 and 52,000 annual start-ups of unincorporated retail stores. In 1985, the number of start-ups decreased to 30,000 stores, and in 1988 to 25,000 (Source: Census of Commerce).

The shop-type characteristics seem to influence market shares when measured by the amount of sales more than market shares when measured by the number of firms. In the case of amount of sales all 15 (five characteristics times three size-classes) coefficients are negative, and six are statistically significant. In the case of number of stores, 10 out of 15 coefficients are negative, and four are statistically significant. There is a weak tendency for the coefficients of the time-dummy variables to decline more over time for the number of firms than for the amount of sales. When comparing the influence of a general time trend versus that of the competitive advantages of large stores on the decline of small store presence, we notice that the former is more pronounced when explaining small store presence when measured by the number of firms and that the latter is more pronounced when explaining small store presence when measured by the amount of sales.

The expected rise (towards zero) of parameter estimates over the size classes is indeed observed for the change in share in consumer expenditure, the change in inventory turnover, and economies of scale. Medium-sized stores appear to be affected only in a limited way by a growing share in consumer expenditure, growing inventory turnover, and growing diversification when compared with very small firms. Probably, small firms experience growing competition from newly established medium-sized firms whereas existing medium-sized firms are legally protected from large store competition.

\section{Conclusion}

This study examines the determinants of the development of small store presence. We provide empirical evidence on whether the competitive advantages of large retail stores are sufficient to 
overcome a hostile environment to enlarge market shares. A fixed effects multinomial logit market share model is used to investigate their influence. We find large stores gaining market share in shop-types accounting for an increased share in total consumer expenditure and in shop-types with an increasing inventory turnover and diversification. These large stores do not seem to be able to profit from scale economies in labour use. The ousting of smallness in Japanese retailing is not only influenced by these factors but also by a general trend in time probably related to a declining interest to become self-employed in the retailing sector. Future research should focus on the consequences of these developments for export opportunities of American and European firms. This should provide an important insight into the effect of the Japanese retail structure on the 'openness' of the Japanese market.

\section{References}

Acs, Z.J. and D.B. Audretsch, 1989a, Small firms in U.S. manufacturing: A first report, Economics Letters 31, 399-402.

Acs, 7.I. and D.R. Audretsch 1989b, Entrepreneurial strategy and the presence of small firms, Small Business F.conomics $1,193-213$.

Batzer, E. and H. Laumer, 1989, Marketing strategies and distribution channels of foreign companies in Japan (Westview Press, Boulder, CO).

Bestor, T.C., 1989, Neighborhood Tokyo (Stanford University Press, Stanford, CA).

Caves, R.E. and M. Uekusa, 1976, Industrial organisation in Japan (The Brookings Institution, Washington, DC).

Census of Commerce, 1972, 1974, 1976, 1979, 1982, 1985 and 1988, Compiled by the Research and Statistics Department, Minister's Secretariat, Ministry of International Trade and Industry, Tokyo.

Cooper, L.G. and M. Nakanishi, 1988, Market-share analysis (Kluwer, Boston, MA).

Flath, D., 1990, Why are there so many retail stores in Japan?, Japan and the World Economy 2, 365-386.

Kirby, D.A., 1983, Government policies towards the small retail business in Japan, International Small Business Journal 2 , $44-58$.

Kurebayashi, S., 1991, Present situation and future prospect of Japan's distribution system, Japan and the World Economy $3,39-60$.

Montgomcry, D.B., 1991, Understanding the Japanese as customers, competitors and collaborators, Japan and the World Economy 3, 61-91.

Patrick, H.T. and T.P. Rohlen, 1987, Small-scale family enterprises, in K. Yamamura and Y. Yasuba, eds., The political economy of Japan, Vol. 1: The domestic transtormation (Stanford University Press, Stantord, CA) 331-384.

Potjes, J.C.A., M.A. Carree and A.R. Thurik, 1992, Retail stores in Japan: regulation, demand and the dual labour market, Report 9245/A, Econometric Institute, Erasmus University Rotterdam, Rotterdam.

Ravesloot, T.K. and W.J.P. Vogelesang, 1989, Facts and figures on retailing in the Netherlands, Europe and the US, Research Institute for Small and Medium-Sized Business, Zoetermeer.

Schwalbach, J., 1989, Small business in German manufacturing, Small Business Economics 1, 129-136.

Suzuki, Y., 1991, The Large Retail Store Law, presentation at the Second Annual Global Marketing Conference: The Japanese Distribution System, American Marketing Association, 24-26 November 1991, Honolulu, HI.

US International Trade Commission, 1990, Phase I: Japan's distribution system and options for improving U.S. access, USITC publication 2291, Washington, DC.

White, L.J., 1982, The determinants of the relative importance of small business, Review of Economics and Statistics 64 , $42-49$. 